\title{
THE IMPLEMENTATION OF GUIDED INQUIRY LEARNING MODEL TO ENHANCE STUDENTS' CRITICAL THINKING SKILLS ON REACTION RATE TOPIC: THE CASE OF AN INDONESIAN PUBLIC SCHOOL
}

\author{
Efi Pujianti Puspita Dewi*, Ratman, Kasmudin Mustapa \\ Universitas Tadulako, Jalan Soekarno Hatta No.KM. 9, Tondo, Mantikulore, Kota Palu, Sulawesi \\ Tengah 94148
}

\begin{abstract}
Abstrak - Tujuan utama dari penelitian ini adalah untuk mengetahui apakah penerapan model pembelajaran inkuiri terbimbing dapat meningkatkan kemampuan berpikir kritis siswa pada materi laju reaksi di SMA Negeri 1 Rio Pakava. Jenis penelitian ini merupakan penelitian pra-eksperimen. Desain penelitian yang digunakan yaitu pretestposttest design. Sampel dalam penelitian ini yaitu terdiri dari dua kelas, dimana kelas XI IPA 2 sebagai kelas eksperimen 1 dan XI IPA 3 sebagai kelas eksperimen 2. Untuk mengukur kemampuan berpikir kritis siswa digunakan instrumen berupa tes kemampuan berpikir kritis dan lembar observasi. Berdasarkan data yang diperoleh kemampuan berpikir kritis siswa kelas eksperimen 1 adalah 44\% siswa termasuk kedalam kategori sangat tinggi, 36\% siswa termasuk kedalam kategori tinggi, dan 20\% siswa termasuk kedalam kategori sedang. Sedangkan untuk kelas eksperimen 2 diperoleh kemampuan berpikir kritis siswa, 52\% siswa termasuk kedalam kategori sangat tinggi, 24\% siswa termasuk kedalam kategori tinggi, dan 24\% siswa termasuk kedalam kategori sedang. Selain itu hasil pengujian N-Gain dimana rata-rata untuk kelas eksperimen 1 sebesar 0,75 yang termasuk kedalam kategori tinggi dan untuk kelas eksperimen 2 sebesar 0,77 yang termasuk kedalam kategori tinggi. Hal tersebut menunjukkan bahwa penerapan model pembelajaran inkuiri terbimbing dapat meningkatkan kemampuan berpikir kritis siswa pada materi laju reaksi.
\end{abstract}

\section{Kata kunci: Inkuiri terbimbing, kemampuan berpikir kritis, laju reaksi}

\begin{abstract}
The main objective of this research was to find out whether the implementation of guided inquiry learning model can improve students' critical thinking skills on the reaction rate topic at one public school located in Central Sulawesi, Indonesia. Experimental research method was used in this study pretest-posttest design. Two science program classes at the grade 11 were recruited. Both were assigned as experimental class 1 and experimental class 2. To measure students' critical thinking skills, the instruments used were critical thinking skills tests and observation sheets. Findings suggest that the critical thinking skills of students in the experimental class 1 was $44 \%$ which was in the very high category, $36 \%$ of them included in the high category ,and $20 \%$ included in the medium category. In contrast, in the experimental class 2 , students' critical thinking skills were $52 \%$ and included in the very high category, $24 \%$ of them included in the high category, and $24 \%$ included in the medium category. In addition, the $\mathrm{N}$-gain test showcased that the average value for experimental class 1 was 0.75 (the high category) and experimental class 2 was 0.77 (the high category). Our findings concluded that the guided inquiry learning model can improve students' critical thinking skills on the reaction rate topic.
\end{abstract}

Keywords: Guided inquiry, critical thinking skills, reaction rate

\footnotetext{
*Corresponding author: Universitas Tadulako, Jalan Soekarno Hatta No.KM. 9, Tondo, Mantikulore, Kota Palu, Sulawesi Tengah 94148, Indonesia. Email:
} 


\section{INTRODUCTION}

Recently, technological advancements have changed rapidly. The development of technology triggers many aspects of human life in terms of education, economy, health, and other fields. In the field of education, for example, advanced learning is needed to prepare students both in academic and global challenges (Kuhlthau, 2010). Therefore, the government seeks to achieve this orientation by implementing various curricula in Indonesian schooling sectors. The curriculum in education is significant since it is used as a guide to achieving educational goals.

Based on the 2013 curriculum, one of the goals to be achieved in secondary school learning is that students have high-level thinking skills. Higher-order thinking skills are an important aspect of the teaching and learning process. One of the higher-order thinking skills is the ability to think critically. Critical thinking is the ability to solve problems through an investigation so as to produce conclusions or rational decisions (Ennis, 1996). In addition, according to Nasution (2018), critical thinking skills are a high-level thinking process that allows one to investigate the evidence, assumptions, or logic that underlies the ideas of others.

In relation to critical thinking skills, chemistry learning encompasses discovery learning processes so that not only knowledge in the form of facts, concepts, or principles is learned by students, but also in the process of gaining this knowledge, students are expected to learn the ability to think critically, logically, creatively, and innovatively (Firdausichuuriyah \& Nasrudin, 2017). Studying chemistry as an exact subject has been considered a very difficult and confusing field of study by many students.

Chemistry learning topic consists of a variety of subject matters, one of which is reaction rate. Reaction rate topic is one of the concepts of the ability to explain abstract phenomena and scientific theories. Reaction rate topic has a standard of competence that students must achieve, which is understanding plant theory (collision) to explain chemical reactions, analyze the factors that influence the rate of reaction, and determine the order of reaction based on experimental results. From these basic competencies, it is clear that the characteristics of the subject matter of the reaction rate covers a collision theory to explain chemical reactions, whereas, for the factors that affect the reaction rate, its application in daily life is given. Since it is an application, the teaching should be geared using the experimental method. By conducting experiments directly in the laboratory, students can directly observe the changes that occur, which in turn can understand themselves the concepts to be learned, so that learning that occurs is more beneficial for students and can train students' critical thinking skills.

Based on our observations and interviews with one of the chemistry teachers at one public school based in Central Sulawesi, Indonesia, students' interest in chemistry, especially in the reaction rate topic, is relatively low, so the learning outcomes do not meet the minimum graduation criteria (KKM). This proves that many students do not understand the chemical topic, and they only memorize certain formulas and understandings to work on calculation problems without understanding the meaning of the learning. This has impacted on students' low retention. Anchored by the importance of chemistry learning for students' critical thinking skills, an appropriate learning model is needed to motivate and facilitate students in developing their critical thinking skills. Students' learning enactment on reaction rate topic should be regarded as an important factor of enhancing their critical thinking skills. This can be done through an effective learning model applied in the classroom.

One alternative learning model that allows the development of critical thinking skills in the reaction rate topic is the guided inquiry learning model. This learning model is geared under a student-centered approach that emphasizes the process of thinking critically and analytically to 
find answers to the problems (Kuhlthau, 2010). It is the opposite of direct learning, which focuses on the teacher as a source of learning (Hajrin et al., 2019). Through the guided inquiry learning model, students attempt themselves to find solutions to problems so as to produce meaningful knowledge (Suyono, 2019). In addition, guided inquiry learning can develop scientific thinking that places students as learners in solving problems and obtaining inquiry knowledge so that they can understand scientific concepts and improve their critical thinking skills (Rahmadhani \& Novita, 2018).

In this study, the guided inquiry learning model employed a contextual approach. Knowledge and skills gained by students are expected not only from remembering facts but discovering the core of the subject matter by themselves. In addition, students' critical thinking skills do require practice and guidance so that their abilities improve (Herunata et al., 2020). In the reaction rate topic, learning discovery can be done by conducting experiments in the laboratory. By conducting experiments, students can directly observe the changes that occur, which in turn can understand their concepts to be learned and can practice critical thinking skills (Lumentut et al., 2017).

Guided inquiry learning motivates students to find answers to problems. Meanwhile, finding answers to problems is the ability to think critically. The activities of students involved in guided inquiry learning include observation, asking questions, testing hypotheses, proving experimentally, giving simple explanations, giving further explanations, predicting, and presenting their results. The activity is largely a critical thinking ability. Thus, guided inquiry-based learning can improve thinking skills, both directly and indirectly. Students who involve in inquiry learning are well-prepared for their critical thinking skills (Rafiqa et al., 2017). Given by the fact that guided inquiry learning is plausible to enhance students' critical thinking skills, the present study was carried out to examine the implementation of such a learning enactment and how it enhanced the students' critical thinking skills.

\section{METHOD}

This study was set out at one public school located in Central Sulawesi, Indonesia, using an experimental research method with posttest and pretest design. Participants involved were 75 science program students in grade 11 . We recruited the participants using a purposive sampling technique. It enabled us to invite participants proposed by the chemistry teacher. In addition, the reason for opting such a sampling technique was because the participants learned in nonheterogenous classes.

A set of critical thinking skills questionnaire was disseminated to the participants. It consisted of ten different questions that had been validated by an expert to determine the validity category of each item and were considered appropriate to be used to identify students' critical thinking skills. Questions on thinking skills tests are presented in Appendix 1.

To measure the ability to think critically, 10 problem questions were given in which each indicator was represented by 2 questions. Indicators of giving simple explanations were measured using questions number 3 and 6. Furthermore, indicators of developing basic skills were measured using questions number 1 and 4 . Indicators of drawing conclusions were measured using questions numbers 7 and 9. Indicators of giving further explanations were measured using questions numbers 8 and 10. Finally, indicators of arranging strategy and tactics were measured using questions number 2 and 5 . 


\section{Data analysis procedure}

This study employed instruments in the form of tests of critical thinking skills and assessment of teaching and learning processes. The assessment of the learning process was carried out using the observation sheet covering four assessment criteria, such as excellent $(\mathrm{E})$, good $(\mathrm{G})$, poor $(\mathrm{P})$, and very poor (VP).

Table 1. Teacher Classroom Teaching Observation Sheet

\begin{tabular}{|c|c|c|c|c|c|}
\hline \multirow[t]{2}{*}{ No } & \multirow{2}{*}{ Observed Aspects } & \multicolumn{4}{|c|}{ Assessment } \\
\hline & & VP & $\mathbf{P}$ & G & $\mathbf{E}$ \\
\hline A. & Pre-Teaching & & & & \\
\hline 1. & Putting in order the classroom atmosphere & & & & \\
\hline 2. & Asking students to pray before learning & & & & \\
\hline 3 & Generating student interest and attention & & & & \\
\hline 4. & Generating motivation (encouragement) to learn & & & & \\
\hline 5 & Delivering learning objectives & & & & \\
\hline 6. & $\begin{array}{l}\text { Asking about the concepts that have been learned relating to } \\
\text { the concepts that will be discussed }\end{array}$ & & & & \\
\hline B. & Whilst-Teaching & & & & \\
\hline 1. & Concept/material development & & & & \\
\hline 2. & Involving students with problems/questions & & & & \\
\hline 3. & Form groups fairly and equally & & & & \\
\hline 4. & Directing students to discuss the results of each thought & & & & \\
\hline 5. & Directing students to form hypotheses & & & & \\
\hline 6. & Guiding students in designing experiments & & & & \\
\hline 7. & $\begin{array}{l}\text { Guiding students to gather information from the objects } \\
\text { provided }\end{array}$ & & & & \\
\hline 8 & Guiding students in analyzing & & & & \\
\hline 9 & Guiding students in compiling observations & & & & \\
\hline 10. & Directing students to present the results of the discussion & & & & \\
\hline 11. & Directing students to respond to their friends' presentations & & & & \\
\hline 12. & Giving direction and align the results of group presentations & & & & \\
\hline 13. & $\begin{array}{l}\text { Encouraging students to make conclusions based on the results } \\
\text { of data analysis they obtain. }\end{array}$ & & & & \\
\hline C. & Post-Teaching & & & & \\
\hline 1. & Providing material reinforcement & & & & \\
\hline 2. & $\begin{array}{l}\text { Giving direction to students to learn the continuation of the } \\
\text { material }\end{array}$ & & & & \\
\hline 3. & Closing the learning with greetings & & & & \\
\hline
\end{tabular}

Table 2. Students' Learning Observation Sheet

\begin{tabular}{|l|l|l|l|l|l|}
\hline No & \multicolumn{1}{|c|}{ Observed Aspects } & \multicolumn{3}{c|}{ Assessment } \\
\cline { 4 - 6 } & \multicolumn{1}{|c|}{ VP } & \multicolumn{1}{|c|}{ P } & \multicolumn{1}{|c|}{ G } & E \\
\hline A. & Pre-Learning & & & & \\
\hline 1. & Students pray according to their beliefs & & & & \\
\hline 2. & The enthusiasm of students in preparing for learning & & & \\
\hline 3 & $\begin{array}{l}\text { Students convey the concepts that have been learned relating to } \\
\text { the concepts that will be discussed }\end{array}$ & & & & \\
\hline B. & Whilst-Learning & & & \\
\hline 1. & Student activities in the learning process & & & \\
\hline 2. & The enthusiasm of students in participating in learning activities & & & \\
\hline 3. & Student attention to teacher instruction & & & & \\
\hline 4. & The ability of students to analyze problems & & & \\
\hline 5. & The ability of students to form hypotheses & & & & \\
\hline 6. & The ability of students to unite opinions with their group & & & \\
\hline
\end{tabular}


The Implemetation of Guided Inquiry Learning Model to Improve Students' Critical Thinking Skills...

\begin{tabular}{|l|l|l|l|l|l|}
\hline 7. & The ability of students to design and conduct experiments & & & & \\
\hline 8. & The ability of students to collect experimental data & & & & \\
\hline 9. & The ability of students to analyze the results obtained & & & & \\
\hline 10. & Students' ability to match hypotheses & & & & \\
\hline 11. & The ability of students to write the results obtained & & & & \\
\hline 12. & The ability of students to present observations & & & & \\
\hline 13. & Interaction between students & & & & \\
\hline 14. & Student involvement in drawing conclusions & & & \\
\hline C. & Post-Learning & & & \\
\hline 1. & Student attention to teacher instruction & & & & \\
\hline
\end{tabular}

We then calculated data from both teacher classroom teaching and students' learning observations using the following formula:

$$
\% \text { Activity }=\frac{\text { Frequency ofactivity }}{\text { Sum of all activities }} \times 100 \%
$$

Table 3. Criteria for assessing teacher and student activity

\begin{tabular}{cc}
\hline Activity $(\%)$ & Criteria \\
\hline $80-100$ & Excellent \\
$66-79$ & Good \\
$56-65$ & Fair \\
$46-55$ & Poor \\
$\leq 40$ & Failed \\
\hline
\end{tabular}

(Sudijono, 2013).

The measurement of critical thinking skills in this study was illustrated through students' answers to problems in the questions. Determining the value of the percentage of critical thinking (NP) was calculated through the following equation:

$$
\text { Percentage }(\%)=\frac{\text { Raw Score }}{\text { Maximum Ideal Score }} \times 100 \%
$$

Table 4. Critical thinking skills categories

\begin{tabular}{cc}
\hline Interpretation $(\%)$ & Categories \\
\hline $81.25<\mathrm{NP} \leq 100$ & Very High \\
$71.50<\mathrm{NP} \leq 81.25$ & High \\
$62,50<\mathrm{NP} \leq 71.50$ & Medium \\
$43,75<\mathrm{NP} \leq 62.50$ & Low \\
$0<\mathrm{NP} \leq 43.75$ & Very Low \\
\hline
\end{tabular}

(Diani et al., 2017).

The data were processed and analyzed using descriptive statistical methods, namely by using the N-Gain (g) test equation (Hake, 1998).

$$
g=\frac{\text { Posttest }- \text { Pretest }}{\text { Maximum Score }- \text { pretest }}
$$

Categories:

g-high $\quad=\mathrm{g} \geq 0,70$

g-medium $\quad=0.30 \leq \mathrm{g}<0.70$

g-low $\quad=g<0.30$ 


\section{RESULTS AND DISCUSSION}

\section{Teacher Classroom Teaching}

Teacher activity assessment data were obtained through observations in the experimental classes 1 and 2 at each meeting using the observation sheet. The results obtained can be seen in Table 5 .

Table 5. Teacher classroom teaching observation

\begin{tabular}{ccc}
\hline \multirow{2}{*}{ Meeting } & \multicolumn{2}{c}{ Classroom Activities (\%) } \\
\cline { 2 - 3 } & Experiment 1 & Experiment 2 \\
\hline Meeting 1 & 84.09 & 82.9 \\
Meeting 2 & 80.7 & 85.2 \\
Meeting 3 & 81.8 & 84.1 \\
\hline Average & 82.20 & 84.09 \\
\hline
\end{tabular}

Based on Table 5, observations of teacher classroom teaching conducted during three meetings have been increased at each meeting so that an average percentage of $82.20 \%$ in the experimental class 1 and $84.09 \%$ in the experimental class 2 are included in the very good category. It occurs because the teacher continues to conduct a self-evaluation related to the results of the assessment of learning at the previous meeting so that all the steps of the guided inquiry model can be applied properly. When all the steps have been applied, one of the researchers who acts as the teacher acquire skills in teaching so that it affects the students' critical thinking abilities.

This is in line with previous research done by Alwiyah dan Imaniyati (2018), who maintained that teacher teaching skills include as new pedagogical competencies such as the ability of teachers to guide student learning activities. The influencing factor is the teacher who continues to carry out evaluations related to the learning process that has been done.

\section{Students' classroom activities}

Student activity assessment data were obtained through observations in the experimental classes 1 and 2 at each meeting using the observation sheet. The results obtained can be seen in Table 6 .

Table 6. Student learning activities

\begin{tabular}{ccc}
\hline \multirow{2}{*}{ Meeting } & \multicolumn{2}{c}{ Classroom Activities (\%) } \\
\cline { 2 - 3 } & Experiment 1 & Eksperimen 2 \\
\hline Meeting 1 & 82 & 83 \\
Meeting 2 & 86 & 85 \\
Meeting 3 & 86 & 85 \\
\hline Average & 84.72 & 84.26 \\
\hline
\end{tabular}

Based on Table 6 , the observations of student activities conducted during three meetings also increased at each meeting so that an average percentage of $84.72 \%$ for the experimental class 1 and 84.26 for the experimental class 2 and these were included in the excellent category. This is due to the interaction and emotional connection between students and teachers who become tighter in each meeting so that students feel more comfortable in the learning process in their class.

This is in line with previous research carried out by Febriyanti and Seruni (2015), who contended that student and teacher interaction is a determinant of student success in learning. Teachers who have high professionals will always establish good interactions with their students. A good teacher will attract the attention of students and engage them in the learning process. 
The percentage of students' learning activities in the class shows that the elements of the guided inquiry learning model are well implemented (Qomaliyah et al., 2017). In addition, the guided inquiry learning model involves the active role of students, so they give positive responses and can understand the topic learned in the class (Hariani et al., 2020).

\section{Critical thinking skills analysis from pretest and posttest}

In this section, the data obtained from the results of the pretest and posttest of students' critical thinking skills in the experimental class 1 and 2 are presented in Table 7.

Table 7. Students' critical thinking skills

\begin{tabular}{ccccc}
\hline \multirow{2}{*}{ Category } & \multicolumn{2}{c}{ Pretest } & \multicolumn{2}{c}{ Posttest } \\
\cline { 2 - 5 } & $\operatorname{Exp} 1(\%)$ & $\operatorname{Exp} 2(\%)$ & $\operatorname{Exp~1~}(\%)$ & $\operatorname{Exp~2(\% )}$ \\
\hline Very High & 0 & 0 & 44 & 52 \\
High & 0 & 0 & 36 & 24 \\
Medium & 0 & 0 & 20 & 24 \\
Low & 0 & 0 & 0 & 0 \\
Very Low & 100 & 100 & 0 & 0 \\
\hline
\end{tabular}

Based on Table 7, students' critical thinkng skills after the pretest is included in the very low category. However, after the implementation of the guided inquiry learning model, there is an increase in the posttest from the category of medium, high, and very high.

Guided inquiry can improve students' critical thinking skills since they are expected to investigate important chemistry concepts and principles individually and cooperatively based on the topic taught (Bilgin, 2009). This is in accordance with research carried out by Jayadinata and Gusrayani (2016) who claimed that guided inquiry learning engages students to find out answers to the problems and enhances their critical thinking skills through various meaningful activities such as hypothesizing, asking, responding, conducting experiments, testing hypotheses, and concluding.

\section{Analysis of critical thinking skills indicators}

\section{Indicator of giving simple explanations}

In this study, we documented a picture of students' critical thinking skills in the form of giving a simple explanation in the experimental class 1 and experiment 2 . It can be seen in Table 8.

Table 8. Indicator of giving simple explanations

\begin{tabular}{ccccc}
\hline Categories & \multicolumn{2}{c}{ Pretest } & \multicolumn{2}{c}{ Posttest } \\
\hline Very High & $\operatorname{Exp} 1(\%)$ & $\operatorname{Exp} 2(\%)$ & $\operatorname{Exp} 1(\%)$ & $\operatorname{Exp} 2(\%)$ \\
High & 0 & 0 & 36 & 56 \\
Medium & 0 & 0 & 56 & 44 \\
Low & 0 & 0 & 8 & 0 \\
Very Low & 12 & 4 & 0 & 0 \\
\hline
\end{tabular}

The data in Table 8 shows an increase in students' critical thinking skills, where at the time of the pretest, students were included in the category of very low category which then after the application of the guided inquiry learning model, their critical thinking skills increased and included in the category of moderate, high, and very high. 
The indicator of giving simple explanations leads students to focus on questions. Students learn to think critically and gradually through learning activities in the form of formulating problems and answering questions that require explanation (Leicester \& Taylor, 2010).

\section{Indicator of developing basic skills}

Table 9 displays an overview of students' critical thinking skills under the indicator of developing basic skills enacted in both experimental classes 1 and 2 .

Table 9. Indicator of developing basic skills

\begin{tabular}{ccccc}
\hline Categories & \multicolumn{2}{c}{ Pretest } & \multicolumn{3}{c}{ Posttest } \\
\hline Very High & $\operatorname{Exp~1(\% )}$ & $\operatorname{Exp~2(\% )}$ & $\operatorname{Exp~1(\% )}$ & $\operatorname{Exp~2(\% )}$ \\
High & 0 & 0 & 48 & 72 \\
Medium & 0 & 0 & 44 & 24 \\
Low & 0 & 0 & 8 & 4 \\
Very Low & 4 & 12 & 0 & 0 \\
\hline
\end{tabular}

Table 9 shows the increase in students' critical thinking skills on the indicator of developing basic skills, where at the time of the pretest, both classes were in the low and very low categories. After the implementation of guided inquiry and posttest, there was an increase where both classes included in the category of medium, high, and very high.

The indicator of developing basic skills leads students to observe and consider the results of their observations. Critical thinking directs students to step outside of self-deception by seeing things directly from various angles, then evaluating them through a rigorous process of intellectual activity (Che, 2002).

\section{Indicator of drawing conclusions}

Table 10 documents students' critical thinking skills in the indicator of drawing conclusions.

Table 10. Indicator of drawing conclusions

\begin{tabular}{ccccc}
\hline Categories & \multicolumn{2}{c}{ Pretest } & \multicolumn{2}{c}{ Posttest } \\
\hline Very High & Exp 1 $(\%)$ & $\operatorname{Exp} 2(\%)$ & 44 & $\operatorname{Exp~2(\% )}$ \\
High & 0 & 0 & 32 & 40 \\
Medium & 0 & 0 & 20 & 20 \\
Low & 0 & 0 & 4 & 40 \\
Very Low & 8 & 4 & 0 & 0 \\
\hline
\end{tabular}

Table 10 shows that students' critical thinking skills at the time of the pretest are in the very low and low categories. After the implementation of the guided inquiry learning model and the dissemination of the pretest learning, it is seen that students in the experimental class 1 included in the medium, high, and very high categories, and some of them included in the moderate category. Meanwhile, in the experimental class 2, students fall into the medium, high, and very high categories. 
The indicator of drawing conclusions lead students to identify things that need to be done to draw conclusions in the form of data, reports, principles, assessments, beliefs, or opinions (Zhou et al., 2007).

\section{Indicator of giving further explanations}

Table 11 presents students' critical thinking skills in the form of giving further explanations.

Table 11. Indicator of giving further explanations

\begin{tabular}{ccccc}
\hline Categories & \multicolumn{2}{c}{ Pretest } & \multicolumn{2}{c}{ Posttest } \\
\hline Very High & $\operatorname{Exp} 1(\%)$ & $\operatorname{Exp} 2(\%)$ & $\operatorname{Exp~1~}(\%)$ & $\operatorname{Exp~2(\% )}$ \\
High & 0 & 0 & 82 & 100 \\
Medium & 0 & 0 & 8 & 0 \\
Low & 0 & 0 & 0 & 0 \\
Very Low & 16 & 16 & 0 & 0 \\
\hline
\end{tabular}

In Table 11, it can be seen that when administering a pretest, students fall into the very low and low categories. After the implementation of the guided inquiry learning model, the students' posttest included in the medium, high, and very high categories.

The indicator of giving further explanations drives students to identify terms, consider definitions, identify assumptions, and unify opinions developed through the phase of analyzing data and evidence to build new knowledge (Kristanto \& Susilo, 2015).

\section{Indicator of arranging strategy and tactics}

In the section, our data indicating students' critical thinking skills on the indicator of arranging strategies and tactics in the experimental class 1 and experimental 2 are displayed in Table 12.

Table 12. Indicator of arranging strategies and tactics

\begin{tabular}{ccccc}
\hline Categories & \multicolumn{2}{c}{ Pretest } & \multicolumn{2}{c}{ Posttest } \\
\hline Very High & $\operatorname{Exp~1(\% )}$ & $\operatorname{Exp~2~}(\%)$ & $\operatorname{Exp~1(\% )}$ & $\operatorname{Exp~2(\% )}$ \\
High & 0 & 0 & 56 & 32 \\
Medium & 0 & 0 & 12 & 12 \\
Low & 0 & 0 & 28 & 28 \\
Very Low & 0 & 0 & 0 & 28 \\
\hline
\end{tabular}

The data in Table 12 shows that, during the pretest, it was found that students were in the very low category. Interestingly, after the implementation of the guided inquiry learning model, the posttest revealed that there was an increase where students were included in the low, medium, high, and very high categories.

Indicator of arranging strategies and tactics leads students to determine an action so that they find solutions to the problems to be solved and indirectly train and develop their critical thinking skills (Falahudin et al., 2016). 


\section{$N$-gain test}

$\mathrm{N}$-gain normality is the difference between the pretest and posttest values, which shows an increase in understanding or mastery of students' concepts after the learning process (Fithriani et al., 2016). Increased students' critical thinking skills obtained using $\mathrm{N}$-gain test can be seen in Table 13.

Table 13. N-gain test

\begin{tabular}{cccc}
\hline \multirow{2}{*}{ Classes } & \multicolumn{3}{c}{ N-gain Index Category } \\
\cline { 2 - 4 } & High $(\%)$ & Medium (\%) & Low $(\%)$ \\
\hline Experimental 1 & 76 & 24 & 0 \\
Experimental 2 & 68 & 32 & 0 \\
\hline
\end{tabular}

Based on Table 13, we can infer that students $(76 \%)$ in the experimental class 1 included in the high category, and $24 \%$ of them included in the moderate category. In contrast, in experimental class 2 , it was indicated that $68 \%$ of the students included in the high category, and $32 \%$ of them included in the moderate category. The average $\mathrm{N}$-gain for experimental class 1 is 0.75 , and experimental class 2 is 0.77 , which is included in the high category (Hake, 1998). This shows that the guided inquiry learning model applied in experimental class 1 and experimental class 2 is quite effective in improving students' critical thinking skills. The effectiveness of the guided inquiry learning model is inseparable from various factors, such as students and the learning enactment (Mariana et al., 2015).

\section{CONCLUSION}

This study has indicated that the implementation of guided inquiry learning model can improve students' critical thinking skills within the critical thinking indicators of giving simple explanations, developing basic skills, drawing conclusions, giving further explanations, and arranging strategies and tactics. This also shows that the guided inquiry applied in experimental class 1 and experimental class 2 is quite effective in improving students' critical thinking skills. Thus, it can be concluded that the guided inquiry learning model is an effective pedagogy in teaching reaction rate topic in the chemistry class.

\section{REFERENCES}

Alwiyah, D., \& Imaniyati, N. (2018). Keterampilan mengajar guru dan kesiapan belajar siswa sebagai determinan terhadap hasil belajar siswa. Jurnal Manajerial, 3(4), 95-103.

Anas Sudijono. (2013). Pengantar statistik pendidikan, cet ke-22. h 371.

Bilgin, I. (2009). The effects of guided inquiry instruction incorporating a cooperative learning approach on university students' achievement of acid and bases concepts and attitude toward guided inquiry instruction. Scientific Research and Essays, 4(10), 1038-1046.

Che, F. S. (2002). Teaching critical thinking skills in a Hong Kong secondary school. Asia Pacific Education Review, 3(1), 83-91.

Diani, R., Saregar, A., \& Ifana, A. (2017). Perbandingan model pembelajaran problem based Learning dan inkuiri terbimbing terhadap kemampuan berpikir kritis peserta didik. Jurnal Penelitian Pembelajaran Fisika, 7(2), 147-155.

Ennis, R. H. (1996). A critical thinking. Freeman. 
Falahudin, I., Wigati1, I., \& Ayu, P. (2016). Pengaruh model pembelajaran inkuiri terbimbing terhadap kemampuan berpikir kritiss siswa pada pembelajaran materi pengelolaan lingkungan di SMP Negeri 2 Tanjung Lago, Kabupaten Banyuasin. Bioilmi: Jurnal Pendidikan, 2(2), 92-101.

Febriyanti, C., \& Seruni, S. (2015). Peran minat dan interaksi siswa dengan guru dalam meningkatkan hasil belajar matematika. Formatif: Jurnal Ilmiah Pendidikan MIPA, 4(3), 245-254.

Firdausichuuriyah, C., \& Nasrudin, H. (2017). Keterlaksanaan penerapan model pembelajaran inkuiri terbimbing untuk meningkatkan keterampilan berpikir kritis siswa materi larutan llektrolit dan non elektrolit kelas X SMAN 4 Sidoarjo. Journal of Chemical Education, 6(2), 184-189.

Fithriani, S., Halim, A., \& Khaldun, I. (2016). Penggunaan media simulasi PhET dengan pendekatan inkuiri terbimbing untuk meningkatkan keterampilan berpikir kritis siswa pada pokok bahasan kalor di SMA Negeri 12 Banda Aceh. Jurnal Pendidikan Sains Indonesia, 4(2), 45-52.

Hajrin, M., Sadia, I. W., \& Gunandi, I. G. A. (2019). Pengaruh model pembelajaran inkuiri terbimbing terhadap keterampilan berpikir kritis siswa pada pembelajaran fisika kelas X IPA SMA Negeri. Jurnal Pendidikan Fisika Undiksha, 9(1), 63-74.

Hake, R. R. (1998). Interactive-engagement versus traditional methods. American Journal of Physics, 66(1), 64-74.

Hariani, N. R., Nuswowati, M., \& Winarno, W. (2020). Pengaruh penerapan model inkuiri terbimbing berbantuan e-modul terhadap pemahaman konsep hidrolisis garam. Jurnal Inovasi Pendidikan Kimia, 14(1), 2561-2571.

Herunata, Amayliadevi, R., \& Widarti, H. (2020). Analisis keterampilan berpikir kritis pada indikator memberikan penjelasan lebih lanjut materi hidrokarbon. J-PEK (Jurnal Pembelajaran Kimia), 5(1), 47-58.

Jayadinata, A. K., \& Gusrayani, D. (2016). Pengaruh model pembelajaran inkuiri terbimbing terhadap kemampuan berpikir kritis siswa pada materi energi bunyi. Jurnal Pena Ilmiah, 1(1), 51-60.

Kristanto, Y., \& Susilo, H. (2015). Pengaruh model pembelajaran inkuiri terbimbing terhadap kemampuan berpikir kritis dan hasil belajar IPA siswa kelas VII SMP. Jurnal Pendidikan Dan Pembelajaran Universitas Negeri Malang, 22(2), 197-208.

Kuhlthau, C. C. (2010). Guided inquiry: School libraries in the 21 st century.

Leicester, M., \& Taylor, D. (2010). Critical thinking acrooss the curiculum. McGraw-Hil Open University Press.

Lumentut, R. S., Said, I., \& Mustapa, K. (2017). Pengaruh model pembelajaran guided inquiry dengan mind map terhadap hasil belajar dan motivasi siswa pada materi redoks di kelas X SMA Negeri 5 Palu. Jurnal Akademika Kimia, 6(2), 113.

Mariana, Y., Gani, A., \& Saiful, S. (2015). Penerapan model pembelajaran inkuiri terbimbing untuk meningkatkan keterampilan berpikir kritis dan sikap sosial siswa SMA pada materi kelarutan dan hasil kali kelarutan. Jurnal Pendidikan Sains Indonesia (Indonesian Journal of Science Education), 3(1), 259-270.

Nasution, S. W. R. (2018). Penerapan model inkuiri terbimbing (guided inquiry) dalam meningkatkan kemampuan berpikir kritis pada pembelajaran fisika. Jurnal Education and Development Institut Pendidikan Tapanuli Selatan, 3(1), 1-5.

Qomaliyah, E. N., Sukib, S., \& Loka, I. N. (2017). Pengaruh model pembelajaran inkuiri terbimbing berbasis literasi sains terhadap hasil belajar materi pokok larutan penyangga. Jurnal Pijar Mipa, 11(2), 105-109. 
Rafiqa, Tjandrakirana, \& Soetjipto. (2017). Penerapan perangkatpPembelajaran model inkuiri terbimbing (Guided Inquiry) untuk meningkatkan kemampuan berpikir kritis siswa SMA. Journal of Biology Education, 6(3), 265-273.

Rahmadhani, P., \& Novita, D. (2018). Keterampilan berpikir kritis siswa pada materi laju reaksi di kelas XI MIA SMA Negeri 1 Manyar. 3(2), 19-30.

Suyono. (2019). Inkuiri terbimbing untuk meningkatkan keterampilan proses sains siswa sekolah menengah atas. Jurnal Komunikasi Penidikan, 3(2), 86-91.

Zhou, Q., Wang, Xi., \& Yao, L. (2007). A preliminary investigation into critical thinking of urban xi, an high school students. 2(3), 447-468. 